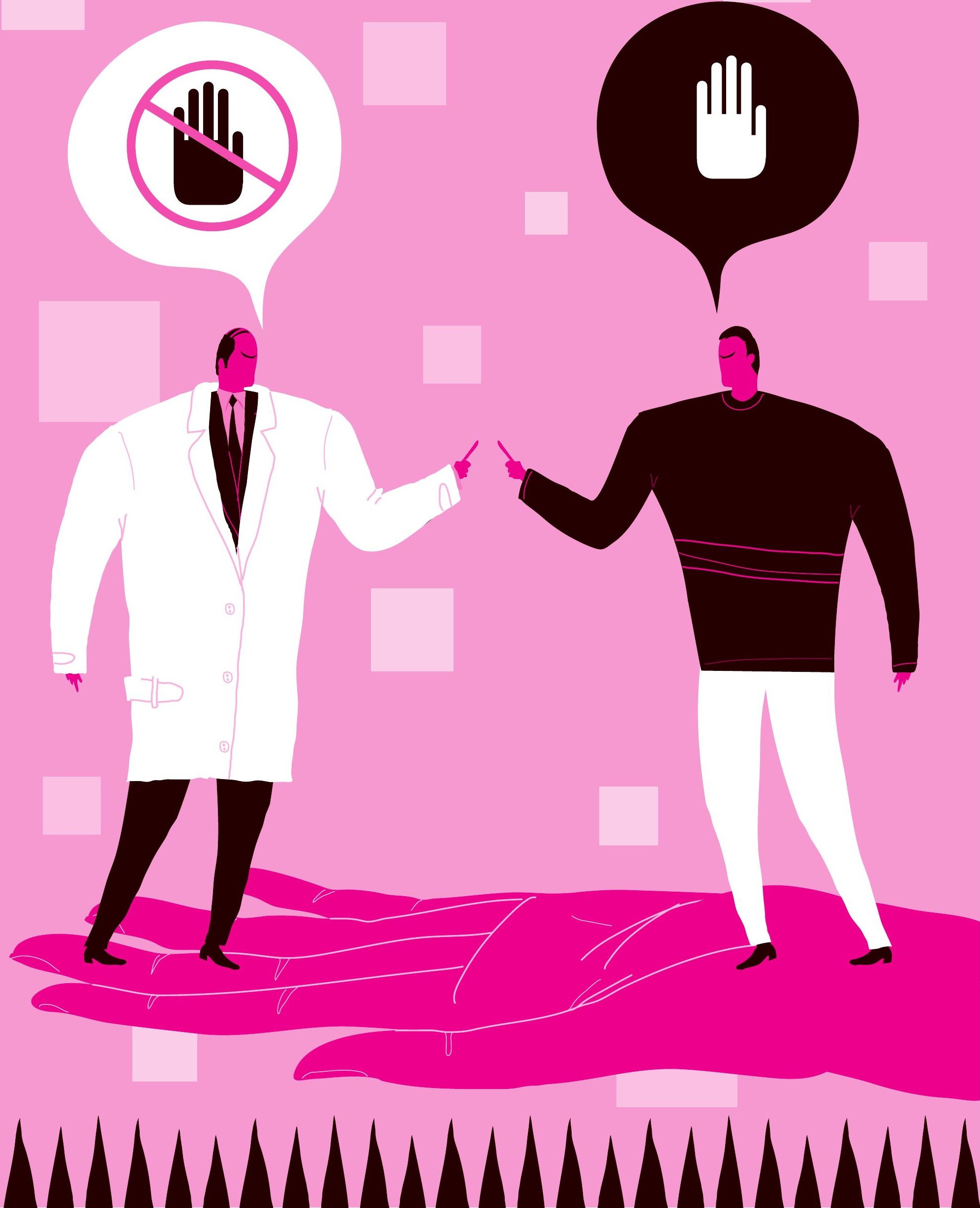




\section{Risk communication between experts and the public: perceptions and intentions ${ }^{1}$}

Lennart Sjöberg

- Professor emeritus and head of the Center for Risk Research at the Stockholm School of Economics, Sweden

- Adjunct professor at the Center for Risk Psychology, Environment, and Safety, Department of Psychology, Norwegian University of Science and Technology, Trondheim, Norway

- lennart.sjoberg@hhs.se

• lennartsjoberg@gmail.com

1 The work on siting and local risk perception and attitudes discussed here was supported by a grant from the Swedish Nuclear Fuel \& Waste Management Co., called SKB in the text. Their homepage is found at http://www.skb.se. I am grateful to Saida Engström and Roland Johansson of SKB for discussions of the design of the study, as well as to members of a planning group consisting of members of all of the four communities. Discussions with Britt-Marie Drottz-Sjöberg were very helpful in the interpretation of the present results. Johnny and Lena Drottz and Björn Johansson assisted in data collection and Infoscandic AB of Umeå, Sweden, scanned the data. Caroline Nordlund, M. A., assisted the work in various ways, as always in a very efficient and cheerful manner. 


\section{Resumo}

Este estudo desenvolve uma análise conceitual e teórica de comunicação de risco em casos nos quais os especialistas e o público apresentam pontos de vista amplamente divergentes sobre o tamanho de um risco. As aplicações são escolhidas dentre os problemas de gerenciamento de risco inerentes ao manuseio de combustível nuclear usado. Enfatiza-se o fato de que pontos de vista conflitantes apresentam bases muito diferentes. O papel da confiança é analisado e, sendo um tema crucial, é muito mais abrangente do que geralmente se presume. As razões para esta diferença são encontradas em modelos de percepção de risco aplicados a dados de pesquisa sobre percepção de risco e atitudes a ela relacionadas.

PALAVRAS-CHAVE: PERCEPÇÃo de RISCO - ESCOLHA de local • REJEITO NUCLEAR - COMBUSTÍVEL NUCLEAR USADO

\section{Abstract}

This paper develops a conceptual and theoretical analysis of risk communication in cases where experts and the public have widely divergent views of the dimensions of a risk. Applications are chosen from among the risk management problems that are inherent to handling of spent nuclear fuel. One stresses the fact that the conflicting points of views have very different bases. The role of trust is analyzed and, as it is a crucial issue, it becomes much more encompassing than what has usually been assumed. The reasons for this difference can be found in risk perception models applied to survey data concerning risk perception and related attitudes.

KEYWORDS: RISK PERCEPTION • SITING • NUCLEAR WASTE • SPENT NUCLEAR FUEL

\section{Resumen}

Se desarrolla un análisis conceptual y teórico de la comunicación de riesgo en casos en que los expertos y el público presentan puntos de vista significativamente divergentes sobre la dimensión de un riesgo. Se eligen las aplicaciones entre los problemas de gestión de riesgo inherentes al manoseo del combustible nuclear usado y se enfatiza el hecho de que los puntos de vista contrarios presentan bases muy diferentes. Se analiza el papel de la confianza y, aunque se trate de un tema crucial, es mucho más amplio de lo que generalmente se presume. Las razones para esta profunda diferencia se encuentran en modelos de percepción de riesgo aplicados a datos de investigación sobre percepción de riesgo y actitudes relacionadas con esta última.

PALABRAS CLAVE: PERCEPCIÓN DE RIESGo - ELECCIÓN DE LUGAR - RECHAzO NUCLEAR • COMBUSTIBLE NUCLEAR USADO 
$\mathrm{R}$ isk communication is a relatively new field of research. It was developed in the 1980's following work on risk perception, which had emerged as an interesting and important field of work in the end of the 1970's. As early as 1989, a manual was published (National Research Council, 1989), and reviews are available, e.g. by Renn (1992) and Fischhoff (1995). An updated risk communication manual which deals fairly with the issues involved is that by Lundgren and McMakin (1998).

Some of this work will be treated here. In addition, the present paper reviews some of the risk perception and communication research carried out in the Center for Risk Research of the Stockholm School of Economics, and some of our earlier work. The tensions between parties in a conflict ridden risk management issue were treated in an early paper (SJÖBERG, 1980) which largely stemmed from experience with nuclear power debates in the 1970's, and a later expansion of the frame of reference which was given in later papers (SJÖBERG, 1991, 1998a).

When people communicate, they must achieve at least two purposes: their message must conform to their beliefs and they must be credible. This is obvious because the purpose of communication is the transfer of beliefs to another party, who may be either ignorant about the topic or who may hold beliefs seen as erroneous. Both these conditions are true in many risk communication situations. The type of situation considered here is the one where experts assess the risk to be quite small while the many members of the public have an opposite view and little knowledge beyond that ${ }^{2}$. The setting provided by a concrete example will first be described. Other examples might have brought at least partly different aspects into focus.

The example to be discussed is that of nuclear waste and the siting of a high-level nuclear waste (HLNW) repository. This is a very difficult social and political problem in all countries that have nuclear power. The data cited here come from Sweden, which has a nuclear power program, but of course, similar conceptual analyses can be made in other countries in Western Europe, the USA, Japan and several other countries. A recent European project investigated these matters in depth in France (BARTHE \& MAYS, 1998; MAYS \& EGOUY, 1998), Spain (CEBRIÁN, PRADES \& SOLÁ, 1998;

2 The other major risk communication challenge emerges in situation where the opposite is true: experts perceive a serious risk and many members of the public ignore it. This is the case with some lifestyle risks such as unhealthy diets (SJÖBERG, 2003c), and also with an environmental risk such as indoor Radon gas in homes. 
MENARD, PRADES \& SOLÁ, 1998), and Sweden (SJÖBERG, VIKLUND \& TRUEDSSON, 1998; 1999). In Eastern Europe and the former Soviet Union (FSU), it is possible that a somewhat different discourse will be necessary since trust is much lower in these countries, for historical reasons, but they are beyond the scope of the present paper. There are of course differences also among countries in Western Europe, due to technical, social, and political conditions. Yet, the psychology of risk communication seems remarkably similar.

Why has this particular risk communication problem become so special and difficult to handle? Radioactive waste is, in fact, seen by many members of the public both as a major part of nuclear risks and as a major part of all waste risks (SJÖBERG, 2006b). Expert opinion certainly does not agree with these views. They may have many roots, one being the pending situation with regard to the future of nuclear power in many countries. If nuclear waste cannot be safely sited in permanent storage, the prospects of expanding or even retaining at a constant level, of present nuclear power programs are dim. Hence, nuclear power opponents may see opposition to siting as one way of creating an obstacle to the nuclear program at large. Yet, this cannot be the only source of conflict. Some people are just very strongly opposed to having a local repository in their neighborhoods, as illustrated by the Kynnefjäll vigil, in the Southwestern county of Bohuslän in Sweden (NORESSON, 1985). For almost 20 years, a group of people held a 24-hour watch on an area, which had been named as a possible candidate for a site investigation for a future repository. They withdrew only in 2000, when several other areas were more likely candidates. This may be seen as a dramatic and extreme case of Nimby-ism ${ }^{3}$, yet this is probably a misleading analysis. Nimby attitudes are not a major part of opposition to local repositories, at least not in Sweden (SJÖBERG \& DROTTZSJÖBERG, 2001). The overwhelming majority of opponents object both to nuclear technology as such, and to local siting of radioactive wastes. They do not say "nuclear power is fine and useful to me, but I will not have its wastes sited in my community", but rather "I want to have nothing to do with nuclear power or with its wastes".

Nimby is an example of derogatory expressions that unfortunately exist and tend to exacerbate conflicts and provide no real insights into how people think about these matters. Another example is "radiophobia" which is now fortunately less often used, and should not be used at all (DROTTZ-SJÖBERG \& PERSSON, 1993). Although there are probably some clinical cases where such a term may be appropriate, it is very misleading as an attempt at understanding the thinking of most people who oppose nuclear power or the siting of a local repository.

In order to understand and successfully carry out risk communication with regard to any topic, it is necessary to have a realistic picture of how the parties in the

3 Not-In-My-Backyard or Nimby is a common term for describing opposition to unwanted local facilities. 
communication episode view the issues at hand. A major problem therefore centers on modeling the public's risk perception. Received models have been found to be inadequate, both with regard to the public (SJÖBERG, 2002b) and to experts (SJÖBERG, 2002a). The Psychometric Model (FISCHHOFF, SLOVIC, LICHTENSTEIN, READ \& COMBS, 1978) which apparently seems to be credible to many, and is the basis of the "outrage" approach to risk communication (SANDMAN, 1989; 1993), accounts for only a minor portion of risk perception data and clearly needs to be improved. In the present paper, alternative approaches will be briefly reviewed.

However, any conflict about a societal risk issue requires an analysis also at levels beyond the individual. It requires such analyses to be concrete and take into account the historical, social and political context in which the conflict emerged. The psychological analysis of individual minds is clearly necessary, but the step to the societal level requires new elements of analysis. Micro-psychology cannot become macro-psychology simply by aggregation or "telescoping", by generalizing from one level to the other with no regard to the institutional context and the structural restraint on the events. The theory of social amplification of risk (KASPERSON, 1992; KASPERSON et al., 1988; RENN, BURNS, KASPERSON, KASPERSON \& SLOVIC, 1992) attempts to solve this problem, but a detailed account and discussion of it is beyond the scope of the present paper. It may suffice to say that the theory gives no specific predictions of the outcome of any risk relevant episode. Maybe it would be better to avoid the term theory and to regard it as a pre-theoretical conceptual structure.

The purpose of this paper is to develop a conceptual and theoretical analysis of risk communication in situations where various groups entertain differing views about a risk on quite different bases. I begin with a brief sketch of the situation with regard to the siting of a HLNW repository in Sweden. Then follows a surface view where the concrete issues and the participants in the conflictual communication situation are described. A concluding section takes the discussion a step below the surface and analyzes the situation in terms of political, or rhetorical, communication rather than information transfer or "education".

\section{Current situation with regard to the siting of a HLNW repository in Sweden}

The agent responsible for finding a site is a corporation called Svensk Kärnbränslehantering $\mathrm{AB}^{4}$, or SKB for short. It is owned by the nuclear industry in Sweden, and the Government. The process of siting has been going on for about two decades and encountered many difficulties. Most dramatically, two local referenda in 1995 and 1997 rejected further investigation of feasibility for siting in the respective communities Storuman and Malå in the North of Sweden. However, the process was halted at an

4 In English: Swedish Nuclear Fuel and Waste Management Co. 
earlier stage in several other communities. See Sjöberg et al. (SJÖBERG et al., 1998; 1999) for reviews.

A very brief analysis of the political process can be done as follows. Sweden has several political parties and a proportional system of representation. The two largest parties in Sweden and in most local Councils are the Social Democrats and the Conservatives (called the Moderate party). They are in majority if they join ranks, but they rarely do, of course. However, in the case of siting these two parties have several times united in suggesting a process to be started in their community, only to find that many supporters of the Social Democrats then threatened to switch to supporting either the Left party (formerly the communists), the Environmentalist party or possibly the Center party.

In this situation, the Social Democrats often found it difficult to remain in support of the siting proposal. A somewhat paradoxical switch from Left to Right in local Council majorities could be caused by anti-nuclear opinion changing sides from the Social Democrats to the Center party, since the latter party usually sides with the nonsocialist block in most other issues. This phenomenon was the cause of the unique change of Government in Sweden in 1976 when the Social Democrats were voted out of office for the first time since 1932. The possibility still exists even if it is smaller today since much or most of the strong anti-nuclear opposition is absorbed by the Left party (now enjoying more democratic credibility since the fall of communism in Eastern Europe and the FSU) and the Environmentalists (which did not exist as a political party in 1976).

The goal of the process currently underway is to find a voluntary host ${ }^{5}$. Attempts to find a voluntary community have been going on for a long time, and since 1993, there have been several feasibility studies of communities, which invited SKB to carry out such studies. Three of the municipalities which have had feasibility studies carried out by SKB have been judged to be of interest as possible hosts. The second phase involves actual drilling to assess the quality of bedrock, an undertaking called a site investigation. This is a major undertaking that will take several years to complete. Two site investigations were started in Sweden in 2002, in Östhammar and Oskarshamn, after the local Councils had given their consent. The public opinion has since become more positive to a repository during the course of the site investigations (SJÖBERG, 2006a). On the other hand, there is no sign that opinion in the rest of the country is becoming more positive to a local repository, in spite of a trend towards a clearly more positive attitude towards nuclear power itself (HOLMBERG, 2003).

5 It should be noted that, as a last resort, the Government can decide about siting in spite of local Council opposition or a No in a local referendum about the issue, but all parties concerned want to avoid such a development. 

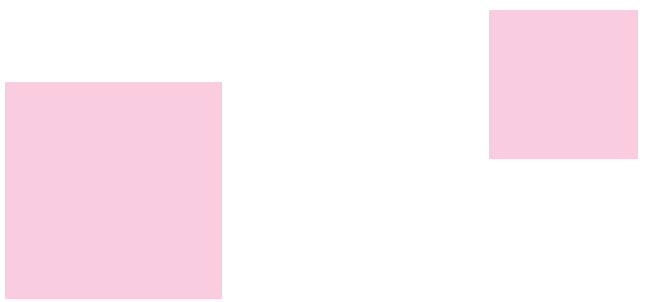

Factors behind the development towards consent for a site investigation in two Swedish municipalities were discussed elsewhere (SJÖBERG, 2003d, 2004b). These are small communities, which already are hosts of nuclear facilities, including low-level nuclear waste management. Regional authorities are not elected by people in the region but appointed by the government, and they have assumed a low profile in the process. Comparing to the situation in the USA, there is no State government, which faces public opposition at a somewhat larger distance from the sites under investigation.

In 2001, a survey study was carried out in the three communities (SJÖBERG, 2006b) ${ }^{6}$. It involved many questions about risk perception, about utilities and about policy attitudes. The background is quite interesting. Previous surveys at the national level (only few local surveys had been conducted) had tended to conclude either that a sizable majority of Swedes were ready to accept a local repository, or that they were very strongly against it ${ }^{7}$. The former conclusion was based on a question, which made implicit assumptions and asked about "acceptance". The latter conclusion was based on a question whether the respondent was "positive" to a local repository.

In the study mentioned it was preferred to ask about policy related intentions, such as how the respondent would vote if there were to be a local referendum on the matter. A similar approach had been taken in an earlier study where experts and the public were compared, with the public represented by a national sample (SJÖBERG \& DROTTZ-SJÖBERG, in press). It was found that a clear majority in two of the municipalities (Östhammar and Oskarshamn) stated that they would vote in favor of a repository and many said they would do so also in the third community (Tierp). A local referendum was regarded as desirable by most of the respondents. The judgment that a democratic decision is called for seems obvious (SJÖBERG, 2001b).

It is important to inquire into the reasons for this accepting attitude. Some of the reasons could be studied in the survey data, and some could not. The latter included dimensions

6 The survey also involved a fourth, neighboring, community (Älvkarleby) which would be involved in transportation of spent nuclear fuel.

7 The message that the Swedish public had accepted a repository in their own community was spread internationally some years ago, see e.g. Flynn et al. (FLYNN et al., 1995). However, this conclusion was based on a leading and ambiguous survey question. When local referenda were held in two Northern communities in 1995 (Storuman) and 1997 (Malå), people there rejected site investigations and hence the possibility of future siting. 
that were probably not within the scope of policy and risk communication activities, such as personality (SJÖBERG, 2003b), and traditional religiosity or "New Age" types of beliefs (SJÖBERG \& af WÅHLBERG, 2002). However, several factors were investigated and they accounted for a very large share (about $65 \%$ ) of the variance of policy attitude (SJÖBERG, 2004a). They were:

- Attitude to nuclear power;

- Risks and benefits of a local repository;

- Trust in authorities and experts;

- Trust in science;

- General tendency towards rating risks as large or small.

It is important to consider, in particular, the role of attitude 8 to nuclear power. Both Oskarshamn and Östhammar are already hosts of nuclear industry. Both of them have nuclear power plants. In addition, Oskarshamn hosts the Swedish national temporary storage facility for spent nuclear fuel (CLAB). Östhammar hosts the corresponding facility for final storage of low and medium level radioactive waste (SFR). The nuclear industry is a large employer in both of these small communities. Furthermore, there is a history of quite competent management of the facilities and no incidents of serious leakage, or attempts to hide such leakage from the public and media. People trust the industry both because many work there and because of its history of competent management of risk. An accepting attitude is often found in populations close to a nuclear facility, see e.g. Williams et al. (WILLIAMS, BROWN \& GREENBERG, 1999).

Yet, they may not have been "positive" to the idea of a repository in their community. Such a facility would bring few benefits by itself (only relatively few jobs). Yet, people in Sweden as a whole, and certainly in these communities, perceive a responsibility that we must manage radioactive waste in a safe manner and that our generation, which has benefited from nuclear power, is the one, which must do it. In addition, almost nobody argues that the waste should be sent somewhere else.

The current situation with regard to siting in Sweden can thus be said to be positive. There are communities which may accept a repository, and which have been found to be likely to be adequate also from technical, geological, and other points of view. But of course, there is still a long way to go before a final decision, which can only be made following a successful site investigation.

8 It is sometimes argued that perceived risk and attitude are semantically overlapping, or even synonyms, and hence that the role of attitude is an artefact. It is easy to see, however, that they are conceptually quite distinct and that the relationship, or its direction, is by no means trivial. The notion of an affect heuristic in risk perception (FINUCANE, ALHAKAMI, SLOVIC \& JOHNSON, 2000) is based on the same relationship, although attitude (liking) is called affect which tends to blur necessary distinctions (SJÖBERG, 2006d). 


\section{A surface view}

\section{The parties}

The people involved in the communication flow are (1) experts, (2) opponents among the public, and (3) proponents among the public ${ }^{9}$. The experts are of course few and one point of view is dominating among them: the risks are negligible when spent nuclear fuel is handled in a competent manner and according to the technical solution, they have developed. However, experts do not usually agree to $100 \%$. There are experts who are independent researchers and who, at times, challenge some of the statements made by mainstream experts. For example, there are some geologists who question the possibility to predict the developments in bedrock over long time periods of thousands of years (SHRADER-FRECHETTE, 1993). Even some risk analysts question the epistemological basis for such knowledge claims (OTWAY \& von WINTERFELDT, 1992).

The role of expert may seem relatively straightforward and it seems to be just common sense to assume experts' risk perception to be governed by objective facts, not emotions or other subjective factors that were found early in the short history of risk research to be of great importance for lay risk perception (FISCHHOFF, SLOVIC \& LICHTENSTEIN, 1982; SLOVIC, FISCHHOFF \& LICHTENSTEIN, 1979). Indeed, this claim was made by Slovic and coworkers and achieved the status of an urban legend. It was simply believed and the empirical basis for it was not scrutinized. However, when the basis is scrutinized it turns out that it has very important limitations (ROWE \& WRIGHT, 2001; SJÖBERG, 2002a). First, only a very small group of risk assessment experts was studied. Second, they were not topical experts in the various fields that were investigated. The fields were quite various and clearly, nobody could be a substantial expert in more than one or two of them. Third, later work has shown that, to the contrary of the traditional claim, experts tend to express risk perceptions of a similar structure as that of lay people, although at a lower level of perceived risk, provided that they make judgments of hazards where they have professional responsibility (SJÖBERG, 1991). It should be added that the statements refer to experts in cases where there is a very small risk, as determined by scientific and technical analysis, while many members of the public hold the risk to be considerable.

There are also many others who are concerned and who are likely to take part in the process, e.g. by voting in a local referendum, but they are seldom active in the risk communication process. It should be noted that these more passive people for this reason alone are quite important for the final decision. In Malå and Storuman, where local referenda were held, voter turnout was very high. See Sjöberg (2003a) for a discussion of "stakeholders" and how they differ from the public at large. An interesting example was given by Löfstedt (2001). Earlier work has shown how involved people differ from others (MILBRATH, 1981). 
The members of the public who are proponents of various technical projects and who rate the risks as very small, or even non-existent, tend to be a group, which is considerably larger than the opponents - about five times larger in our data. In spite of that, they have been little studied. Their risk assessment coincides with that of the experts, but it is not based on independent assessment of the risk, but on trust. There are many interesting research questions left for future work when it comes to this group (SJÖBERG, 2006c).

The group of opponents of course consists of people with little or no technical expertise, at any rate insufficient expertise to form an independent opinion of the issues at hand. They therefore have to trust, or not to trust, what the experts say. Trust may refer to experts or their employers, or it may be in science itself. The former alternative, which may be called social trust, has been discussed by many authors (SLOVIC, 1993; SLOVIC, FLYNN \& LAYMAN, 1991), and the dimensions usually mentioned as trust creating attributes are competence, honesty and caring. Research has shown that trust in experts may be fairly well explained by such attributes (PETERS, COVELLO \& MCCALLUM, 1997). Yet, social trust is insufficient to account for concern, or perceived risk. In most studies, trust has been found to explain only about $10-15 \%$ of the variance of perceived risk (SJÖBERG, 1999). A substantial improvement in explanatory value of risk perception models was obtained when trust in science itself was added. In turn, such trust takes several forms. In one type of assessment, questions are asked about whether there are limits to scientific knowledge. In another type, questions are asked about belief in non-materialistic dimensions of the world, and about the kind of knowledge one may have about them, and how it can be achieved. These latter beliefs are often discussed under the heading "New Age" and they are embraced by a truly astonishing number of people in all countries where they have been investigated, not least in the FSU and other Eastern nations ${ }^{10}$. But similar beliefs are also very common in countries with a different historical experience, both Protestant and Catholic (SJÖBERG \& af WÅHLBERG, 2002).

Skepticism with regard to science reveals a tendency of even broader importance. It questions the very definition of expert. In the received meaning of the term, an expert is somebody with an advanced education on a tropic and with extensive experience from working on it. Formal acknowledgments are also an integral part of expertise, such as a university degree, membership in a professional organization and a license to practice. Yet, expertise may be challenged in a profound manner by people involved in a risk communication episode. Jasanoff even stated that expertise can be quickly attained by anyone (JASANOFF, 1998). Although this is an extreme viewpoint it may well represent the opinions of many members of the public who do claim a right to debate the technical issues of a risk management problem - not only by referring to

10 It seems as if materialistic Marxism only managed to suppress spiritualistic beliefs and never eradicated them. As soon at the apparatus of suppression disappeared, the beliefs surfaced. 


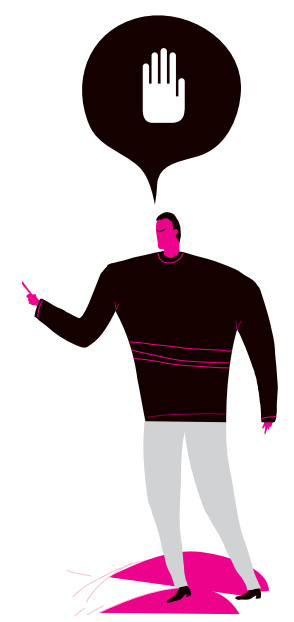

dissenting experts but also by forming their own independent views of a matter. In part, such claims may reflect local knowledge, based for example on observations in nature, which may reveal facts about radioactive fallout not anticipated by experts and truly relevant. In many cases, however, what is believed to be local or individual facts may be quite misleading and causal attributions made on their basis may be quite inadequate. Rumors can play an important role here (KAPFERER, 1989). Individual cases of illness may have many causes, to take an example, and attributing them to a given source of pollution may be unjustified, still quite convincing to many. Something like this appears to have happened in Ukraine where apparently many illnesses were attributed, without convincing scientific evidence, to Chernobyl fallout (DROTTZSJÖBERG et al., 1994). In such cases, there is a dramaturgical logic, which supersedes scientific logic: if there is a culprit, especially connected to earlier attempts to hide the facts and shun responsibility, it gets to be a very persuasive case to argue that various illnesses and/or accidents are caused by the culprit. The causal chain gets to be personalized and there is someone to blame ${ }^{11}$.

\section{The objects}

The objects of communication are simple at a first glance, complex upon reflection. The siting of a repository can mean many things, and the risks involved are multidimensional. Some of the distinctions may be shared by the different parties; others may be subject to misunderstandings.

11 An interesting Swedish case is that of indoor Radon gas. When this environmental danger, which is considerable in many countries such as Sweden and France, was first discussed in Sweden in the 1970's it was associated with the use of a certain type of concrete as building material. While this was true, it was only a minor part of the whole problem of Radon. Most of the indoor Radon comes from natural sources and enters houses in various ways. Once this was realized, there was no longer a culprit, and the risk was even tied to Nature which is predominantly, in Sweden, seen to be very beneficial and friendly. Public involvement disappeared. For a survey of risk perception and communication with regard to Radon, see work by Sjöberg and Fisher (FISHER \& SJÖBERG, 1990; SJÖBERG, 1989). 
A few examples to illustrate the situation may be useful. In the two local referenda in Sweden about siting, the question asked to the electorate was if a site investigation was to be carried out. This is of course a very different question from the one about final siting. Yet, it was hard to make the distinction in the debate (DROTTZ-SJÖBERG, 1998). A positive decision on a site investigation was probably seen by many as a proxy for a final siting decision. Another example: all decisions regarding siting are taken with regard to the spent nuclear fuel produced by the present nuclear program. There are currently no convincing solutions of the problem of how nuclear power can be replaced in its entirety. At the present, nuclear power produces about $50 \%$ of the electricity used in Sweden. Both industries and households are dependent on a reliable and reasonably cheap supply of electricity. Hence, it is very likely that the present nuclear program at one point in the future must be expanded and continue beyond the year 2010, and the volume of spent fuel to be handled by a repository will be increased. Alternatively, several repositories must be constructed. Yet, these matters cannot be discussed in a realistic manner as long as the long-term energy policy of the country remains unsettled, or is lacking in credibility.

\section{The constructions}

In a study of nuclear waste risk perception, experts and the public made judgments of risks as they saw them, and also judgments of how they believed that the other party saw the risks (SJÖBERG, TRUEDSSON, FREWER \& PRADES, 2000). It was found that experts believed that the public saw the risks as larger than they in fact did. On the other hand, the public believed that the experts saw the risks as small, but not quite as small as they in fact did. Hence, both groups erred in the same direction: they thought the other group saw larger risks than they in fact did.

This finding might be related to the very common fining that there is a difference between perceived risk to oneself (personal risk) and to others (general risk). The latter is usually - in fact, almost always - larger than the former. However, in the case of a risk such as the one of nuclear waste, there is no reason to expect that the difference is very large. It is only when the risks are seen as under one's own control that the difference becomes quite large, such as risks of smoking and drinking alcohol, and also a technology risk such as IT risks (SJÖBERG \& FROMM, 2001). Nuclear technology is definitely not believed to be under the control by members of the public. Hence, a small difference between personal and general risk is to be expected and other factors must account for the systematic error in the judgments by the other party.

There are other possible reasons for the finding. The experts get their input from the public through people who are especially concerned and they are likely to hold more extreme views than others (SJÖBERG, 2003a). The public, on the other hand, usually gets its information from experts who are especially assigned to the role of communication with the public (unless they act as independent researchers). It is 
likely that they moderate their message somewhat to fit better in what they believe are the conceptions that the public holds. Confronting an opposed part with a widely divergent view may be seen as counterproductive, and other strategies are thus employed.

\section{Rhetorical communication}

The most obvious approach to understanding the siting debate is to construe it as a question of education or information transfer. After all, the experts agree largely that we are dealing with a very small risk, which can be well managed by means of technical solutions painstakingly developed and at the present well designed ${ }^{12}$. In addition, there is an ethical responsibility involved. People certainly have the right to information and it should be provided. Yet, it may be less efficient than often believed to remain at this level. Other approaches are those of Public Relations or rhetoric.

Can risk communication be construed as advertising and Public Relations? The risk is great that such an approach will contribute to further confusion, since advertising is based on presumptions, which simply do not hold in the typical risk communication case. Most consumer products are low in involvement and quite possibly fairly similar from one brand to another. The consumer is assumed to pay little attention to any message and may well be influenced by various more or less irrelevant cues. However, in risk communication there is a high level of involvement for many actors who see the issue as one involving their own health and that of their families and friends. The "product" that is being "sold" is no simple thing at all.

In risk communication, there is not a question of buying at all, but rather of accepting something, which may be regarded as largely negative. Extensive data have shown that the risk aspects - health and reputation of the area in question - dominate the views that people have of the proposed project. Utility, such as new jobs created, may enter, but with a distinctly lower weight. The related notion that trust building is sufficient was criticized by Trettin \& Musham (2000). Their study is of special interest here because it involved nuclear waste storage problems.

It is clear that many risk communication episodes involve political or rhetorical communication (CORBETT \& CONNORS, 1998). A situation of rhetorical communication contains many dangers and pitfalls. Information exchange is only a part, possibly a minor part, in such a situation. Instead, it is a question of persuasion,

12 This statement refers only to the Swedish situation. In other countries, different conditions, e.g. of geology, may call for a more cautious formulation and experts may take quite different points of view regarding the risks involved in a proposed siting solution. In addition, the very long time perspectives make it quite difficult to predict the safety of a repository (SHRADER-FRECHETTE, 1993). 
and reference is made to external parties who may be the intended and important recipients of the message, not the party to whom it is formally directed. In a case of conflict between two parties, special problems of communication occur. People may differ with regard to beliefs and also values, or goals. The parties may entertain perspectives which involve tactical considerations - what seems like communication is really an attempt to persuade others not directly taking part in communication. There may be hidden agendas. Such hidden agendas may not be conscious but still affect the arguments put forward. In typical rhetorical communication, the arguments are shifting and elastic, and changed and made up as the discussion proceeds. When one argument is met with a seemingly effective counterargument, other arguments are produced in favor of the threatened position. Because of this common way of functioning, risk communication is not well served by construing it as merely a question of information, or even education. Whatever is necessary to reach social consensus, it is not merely information.

In the present application, there is conflict over both goals and beliefs. Since rhetorical communication tends to be, at the surface, about beliefs rather than values some strange phenomena may occur - difficult to understand if the communication situation is not construed as political (SJÖBERG \& MONTGOMERY, 1999).

Consider, first, why communication is not about values. There are several reasons. Values are shared in a culture, and the person who rejects important and shared values takes a great risk. But values are also typically quite vague. They are such things as freedom, equality, quality of life etc. Nobody can come out against them, and even comparing them is difficult and risky. Is freedom more important than equality? Who can tell? And not many people will even agree that there may be a conflict and a necessity to choose. Value conflicts are avoided and serious discussions of them are seldom or never carried out. Instead, the actors dodge such issues and construe the situations in such a manner that no conflicts remain. This is done by twisting the reality side of the argument - the beliefs. Hence, we end up in situations where there are endless and seeming irresolvable disagreements about reality, especially if future realities are at stake.

Just how intractable is the situation? There have been a few historical episodes, which suggest that we are dealing with highly emotional processes and strong prejudice. An often mentioned example is the Goiânia radiation panic (PETTERSON, 1988) in 1987. 
Following a serious, but quite limited, radiation accident in this region of Brazil, there was widespread behavior which was interpreted by Slovic et al. as an example of "stigma" (SLOVIC, LAYMAN et al., 1991). The stigma "model" suggests that there is a very difficult problem for risk communication, and it is important to scrutinize it.

Repository opposition was related to the notion of stigma by Slovic et al. (SLOVIC, FLYNN \& GREGORY, 1994; SLOVIC, LAYMAN et al., 1991). The word refers, of course, to the ancient Greek custom of putting a mark on a criminal so that all could see that he had been found guilty of a serious crime. Goffman made the concept salient in modern social science (GOFFMAN, 1963). A person is stigmatized if it becomes known that he or she has committed certain acts, which are considered shameful and strongly unacceptable. The stigmatized person encounters a hostile social environment and finds it hard to be rehabilitated or accepted again. Strong prejudice is developed as well as strong emotional rejection of the person.

Surely, this process does occur in certain cases. But is it an appropriate description of opposition to a HLNW repository? Not all opposition can be characterized as a case of stigma, to be sure. There must be an accompanying strong emotional reaction and strong prejudice, otherwise stigma is just a (misleading) synonym for opposition. However, the literature on stigma has little to say about such emotional and prejudicial reactions (BROSTRÖM, KESSLING, KRAFFT \& SJÖBERG, 2002). Risk perception is usually not a strongly emotional matter (SJÖBERG, 1998b). It is a matter of intellectual judgment, however much one may question the quality of the inferences that are made.

The use of the stigma concept in the risk communication literature is but an example of the exploitation of common sense notions. Since social and psychological realities rarely are well described by common sense, the use of such notions presupposes that they are not developed or questioned. The further specifics are just ignored. Other examples could be given as well, such as the views on experts discussed in the introduction.

\section{Conclusion}

In order for risk communication to succeed, it must have a realistic working model of the parties who take part in a communication episode. It is necessary to go well beyond explications of common sense, because in social and behavioral science common sense is rarely a good first approximation to truth. Much current work fails in this respect. The received view of risk perception of the public depicts them as quite emotional (LOEWENSTEIN, WEBER, HSEE \& WELCH, 2001), while the experts are seen as rational and objective. The empirical research behind these notions is not sufficient to support them, and the view that now emerges of public, and to some 
extent expert, risk perception is that it is a question of ideology, not emotion. The ideology concepts we have found to be of importance regard "tampering with Nature" (SJÖBERG, 2000) and special ontological and epistemological beliefs (SJÖBERG \& af WÅHLBERG, 2002), connected to beliefs about the limitations of current scientific knowledge (SJÖBERG, 2001a). The theory of risk communication must be developed on a basis of differences in basic beliefs about Nature and about Science. The surface analysis, which stops at noting that the public is either ignorant about technical and scientific facts or simply emotional and feeling intense fear, is bound to fail.

\section{References}

BARTHE, Y. \& MAYS, C. High profile and deep strategy: communication and information practices in France's underground laboratory siting process. A riskpercom national case study on communication and radioactive waste management (Note SEGR No. 98/18). Paris: IPSN, 1998.

BROSTRÖM, L.; KESSLING, A.; KRAFFT, G. \& SJÖBERG, L. Psykosociala effekter av ett djupförvar för använt kärnbränsle. Litterturöversikt och intervjuer med uppsalabor. (psychosocial effects of a depth repository for spent nuclear fuel. Literature review and interviews with residents of Uppsala) (SKB Rapport No. R-02-13). Stockholm: SKB, 2002.

CEBRIÁN, A.; PRADES, A. \& SOLÁ, R. The communication strategy of a Spanish institution about radioactive waste, a riskpercom national cased study. Madrid: Ciemat, 1998.

CORBETT, E. P. J. \& CONNORS, R. J. Classical rhetoric for the modern student. New York: Oxford University Press, 1998.

DROTTZ-SJÖBERG, B.-M. Stämningar i Malå efter folkomröstningen 1997. (Moods in Malå after the 1997 referendum) (Projekt Rapport No. PR D-98-03). Stockholm: SKB, 1998.

DROTTZ-SJÖBERG, B.-M. \& PERSSON, L. Public reaction to radiation: fear, anxiety or phobia? Health Physics, 64, 223-231, 1993.

DROTTZ-SJÖBERG, B.-M.; RUMYANTSEVA, G. M.; MARTYUSHOV, A. N.; ARKHANGELSKAYA, H. V.; NYAGU, A. \& AGEEVA, L. A. Public reactions to the Chernobyl accident. Report from a data collection in 1993 in Russia, Belarus and Ukraine. Social and psychological factors, the joint study project 2 of the European Community. Center for Risk Research, Stockholm School of Economics, 1994.

FINUCANE, M. L.; ALHAKAMI, A.; SLOVIC, P. \& JOHNSON, S. M. The affect heuristic in judgments of risks and benefits. Journal of Behavioral Decision Making, 13, 1-17, 2000.

FISCHHOFF, B. Risk perception and communication unplugged: twenty years of process. Risk Analysis, 15, 137145, 1995.

FISCHHOFF, B.; SLOVIC, P. \& LICHTENSTEIN, S. Lay foibles and expert fables in judgments about risk. American Statistician, 36, 240-255, 1982.

FISCHHOFF, B.; SLOVIC, P.; LICHTENSTEIN, S.; READ, S. \& COMBS, B. How safe is safe enough? A psychometric study of attitudes towards technological risks and benefits. Policy Sciences, 9, 127-152, 1978. 
FISHER, A. \& SJÖBERG, L. Radon risks: people's perceptions and reactions. In: MAJUMDAR, S. K.; SCHMALZ, R. F. \& MILLER, E. W. (eds.). Environmental radon: occurrence, control and health hazards (pp. 398411). Pittsburgh: Pennsylvania Academy of Science, 1990.

FLYNN, J.; CHALMERS, J.; EASTERLING, D.; KASPERSON, R.; KUNREUTHER, H.; MERTZ, C. K. et al. One hundred centuries of solitude. Redirecting America's high-level nuclear waste policy. Boulder, CO: Westview Press, 1995

GOFFMAN, E. Stigma: notes on the management of spoiled identity. Englewood Cliffs, NJ: Prentice-Hall, 1963.

HOLMBERG, S. Kärnkraftsanhängarna vinner terräng. (Supporters of nuclear power gain terrain). In: HOLMBERG, S. \& WEIBULL, L. (eds.). Fåfängans marknad (pp. 91-100). Göteborg: SOM-Institutet, 2003.

JASANOFF, S. The political science of risk perception. Reliability Engineering and System Safety, 59, 91-99, 1998.

KAPFERER, J. N. A mass poisoning rumor in Europe. Public Opinion Quarterly, 53, 467-481, 1989.

KASPERSON, R. E. The social amplification of risk: progress in developing an integrative framework. In: KRIMSKY, S. \& GOLDING, D. (eds.). Social theories of risk (pp. 153-178). Westport: Praeger, 1992.

KASPERSON, R. E.; RENN, O.; SLOVIC, P.; BROWN, H. S.; EMEL, J.; GOBLE, R. et al. The social amplification of risk. Risk Analysis, 8, 177-187, 1988.

LOEWENSTEIN, G. F.; WEBER, E. U.; HSEE, C. K. \& WELCH, N. Risk as feelings. Psychological Bulletin, 127, 267-286. 2001.

LUNDGREN, R. \& MCMAKIN, A. Risk communication. A handbook for communicating environmental, safety, and health risks. Columbus, $\mathrm{OH}$ : Battelle, 1998.

LÖFSTEDT, R. Risk and regulation: boat owners' perceptions of recent antifouling legislation. Risk Management: an International Journal, 3, 33-46, 2001.

MAYS, C. \& EGOUY, R. Mission communication: press office and related activities at France's Institute for Nuclear Safety and Protection (IPSN). A riskpercom cross national case study on institutional communication (Note SEGR No. 98/19). Paris: IPSN, 1998.

MENARD, M.; PRADES, A. \& SOLÁ, R. Analysis of the institutional communication strategy of the nuclear safety council in Spain. A riskpercom common case study. Madrid: Ciemat, 1998.

MILBRATH, L. Citizen surveys as citizen participation. Applied Behavioral Science, 17, 478-496, 1981.

NATIONAL Research Council. Improving risk communication. Washington, DC: National Academy Press, 1989.

NORESSON, J. Å. Kynnet som försätter berg. Munkedal: Bokskogen, 1985.

OTWAY, H. \& von WINTERFELDT, D. Expert judgment in risk analysis and management: process, context, and pitfalls. Risk Analysis, 12, 83-94, 1992.

PETERS, R. G.; COVELLO, V. T. \& MCCALLUM, D. B. The determinants of trust and credibility in environmental risk communication: an empirical study. Risk Analysis, 17, 43-54, 1997.

PETTERSON, J. S. Perception vs. reality of radiological impact: the Goiânia model. Nuclear News, 31, 84-90, 1988.

RENN, O. Risk communication: towards a rational discourse with the public. Journal of Hazardous Materials, 29, 465-519, 1992. 
RENN, O.; BURNS, W.; KASPERSON, R. E.; KASPERSON, J. X. \& SLOVIC, P. The social amplification of risk: theoretical foundations and empirical application. Journal of Social Issues, 48, 137-160, 1992.

ROWE, G. \& WRIGHT, G. Differences in expert and lay judgments of risk: myth or reality? Risk Analysis, 21, 341356, 2001.

SANDMAN, P. M. Hazard versus outrage in the public perception of risk. In: COVELLO, V. T. (ed.). Effective risk communication (pp. 45-49). New York: Putnam Press, 1989.

. Responding to community outrage: strategies for effective risk communication. Fairfax, Va.: American Industrial Hygiene Association, 1993.

SHRADER-FRECHETTE, K. S. Burying uncertainty: risk and the case against geological disposal of nuclear waste. Berkeley, CA: University of California Press, 1993.

SJÖBERG, L. The risks of risk analysis. Acta Psychologica, 45, 301-321, 1980.

Radon risks: attitudes, perceptions and actions (No. EPA-230-04-89-049): U. S. Environmental Protection Agency, Office of Policy Analysis, 1989.

. Risk perception by experts and the public (Rhizikon: Risk Research Report No. 4). Stockholm: Center for Risk Research, 1991.

. Risk perception: experts and the public. European Psychologist, 3, 1-13, 1998a.

Worry and risk perception. Risk Analysis, 18, 85-93, 1998b.

. Perceived competence and motivation in industry and government as factors in risk perception. In: CVETKOVICH, G. \& LÖFSTEDT, R. E. (eds.). Social trust and the management of risk (pp. 89-99). London: Earthscan, 1999.

. Perceived risk and tampering with nature. Journal of Risk Research, 3, 353-367, 2000.

. Limits of knowledge and the limited importance of trust. Risk Analysis, 21, 189-198, 2001a.

Political decisions and public risk perception. Reliability Engineering and Systems Safety, 72, 115$124,2001 b$.

The allegedly simple structure of experts' risk perception: an urban legend in risk research. Science Technology \& Human Values, 27, 443-459, 2002a.

. Are received risk perception models alive and well? Risk Analysis, 22, 665-670, 2002b.

Attitudes and risk perceptions of stakeholders in a nuclear waste siting issue. Risk Analysis, 23, 739749, $2003 a$.

. Distal factors in risk perception. Journal of Risk Research, 6, 187-211, 2003b.

Neglecting the risks: the irrationality of health behavior and the quest for la dolce vita. European Psychologist, 8, 266-278, 2003c.

. Risk perception, emotion, and policy: the case of nuclear technology. European Review, 11, 109-128, 2003d.

. Explaining individual risk perception: the case of nuclear waste. Risk Management: an International Journal, 6, 51-64, 2004a. 
. Nuclear waste risk perceptions and attitudes in siting a final repository for spent nuclear fuel. In: ANDERSSON, K. (ed.) Valdor 2006. Proceedings (pp. 452-460). Stockholm, 2006a.

. Opinion och attityder till förvaring av använt kärnbränsle. (Opinion and attitudes to a repository for spent nuclear fuel) (Research Report No. R-06-97). Stockholm: SKB. Svensk Kärnbränslehantering AB, 2006b.

Rational risk perception: utopia or dystopia? Journal of Risk Research, 9, 683-696, 2006c.

Will the real meaning of affect please stand up? Journal of Risk Research, 9, 101-108, 2006d.

SJÖBERG, L. \& af WÅHLBERG, A. New age and risk perception. Risk Analysis, 22, 751-764, 2002.

SJÖBERG, L. \& DROTTZ-SJÖBERG, B.-M. Fairness, risk and risk tolerance in the siting of a nuclear waste repository. Journal of Risk Research, 4, 75-102, 2001.

SJÖBERG, L. \& DROTTZ-SJÖBERG, B.-M. (in press). Attitudes towards nuclear waste and siting policy: experts and the public. New York: Nova Publishers.

SJÖBERG, L. \& FROMM, J. Information technology risks as seen by the public. Risk Analysis, 21, 427-442, 2001.

SJÖBERG, L. \& MONTGOMERY, H. Double denial in attitude formation. Journal of Applied Social Psychology, 29, 606-621, 1999.

SJÖBERG, L.; TRUEDSSON, J.; FREWER, L. \& PRADES, A. Through a glass darkly: experts' and the public's mutual risk perception. In: COTTAM, M. P.; HARVEY, D. W.; PAPE, R. P. \& TAIT, J. (eds.). Foresight and precaution. Volume 1 (pp. 1157-1162). Rotterdam: A. A. Balkema, 2000.

SJÖBERG, L.; VIKLUND, M. \& TRUEDSSON, J. Attitudes and opposition in siting a high level nuclear waste repository (Rhizikon: Risk Research Report No. 32). Stockholm: Center for Risk Research, 1998.

Attitudes and opposition in siting a high level nuclear waste repository. In: Facility siting: issues and perspectives: Academia Sinica: Columbia Earthscape Research, 1999.

SLOVIC, P. Perceived risk, trust, and democracy. Risk Analysis, 13, 675-682, 1993.

SLOVIC, P.; FISCHHOFF, B. \& LICHTENSTEIN, S. Rating the risks. Environment, 21, 14-20, 36-39, 1979.

SLOVIC, P.; FLYNN, J. \& GREGORY, R. Stigma happens: social problems in the siting of nuclear waste facilities. Risk Analysis, 14, 773-778, 1994.

SLOVIC, P.; FLYNN, J. H. \& LAYMAN, M. Perceived risk, trust, and the politics of nuclear waste. Science, 254, 1603-1607, 1991.

SLOVIC, P.; LAYMAN, M.; KRAUS, N.; FLYNN, J.; CHALMERS, J. \& GESELL, G. Perceived risk, stigma, and potential economic impact of a high-level nuclear waste repository in Nevada. Risk Analysis, 11, 683-696, 1991.

TRETTIN, L. \& MUSHAM, C. Is trust a realistic goal of environmental risk communication? Environment and Behavior, 32, 410-426, 2000.

WILLIAMS, B. L.; BROWN, S. \& GREENBERG, M. Determinants of trust perceptions among residents surrounding the Savannah River nuclear weapons site. Environment and Behavior, 31, 354-371, 1999.

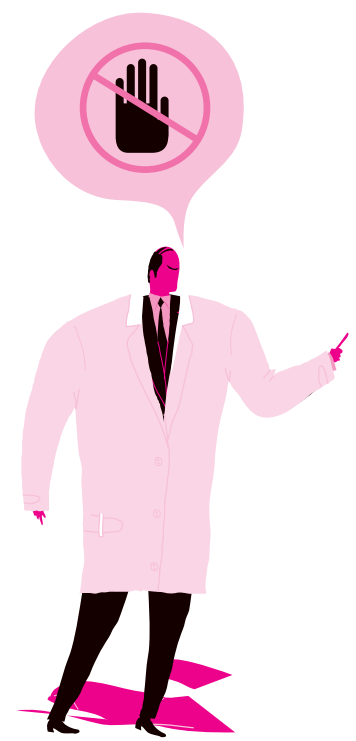

